\title{
STRUCTURE OF SOCIAL COMPETENCE OF FOREIGN STUDENTS
}

The purpose of this article is to analyse the structure of social competence of foreign students and identify components which define clearly the meaning of this concept. Social competence was studied by Ukrainian and foreign scholars taking into account various aspects; the importance of its development for different categories of students was noted; however, the social competence of foreign students was not studied at the appropriate level. Based on methodological approaches (competence, system, culturological, axiological, participatory, environmental) and pedagogical principles, a model of formation of social competence of foreign students was determined, which contains the following components: cognitive, value, activity and communicative.

Cognitive component is characterized by knowledge that allows to socialize effectively; self-conception in social relations; perception of social essence; knowledge and understanding of social roles of a particular society, realization of social reality, social laws of society, where foreign students live. At the core of cognitive component, in our opinion, is the phenomenon of social intelligence. Value component involves the acceptance of standards of social behaviour, the ability to understand and control emotions, understanding and anticipating the emotions of other people, i.e. the presence of emotional intelligence, tolerance, ethics in relationships, empathy. Activity component is realized in behaviour that does not contradict the norms of foreign society, in the ability to cooperate in a group, in the capability to perform various social roles, in effective social adaptation and psychological flexibility. The communicative component is the ability to verbalize thoughts adequately, mastery of techniques of verbal and nonverbal communication, observation of cultural norms in communication, the ability to prevent conflicts, the capability to resolve conflict situations in case of their occurrence.

This structural model reveals the content of social competence of foreign students.

Key words: social competence, foreign student, cognitive component, value component, activity component, communicative component, social intelligence, emotional intelligence, adaptation.

\section{(статтю подано мовою орихіналу)}

The analysis of scientific achievements of native and foreign scientists showed that in modern science there is no single definition of "social competence"; depending on the field of science, researchers have different views on the interpretation of this phenomenon. Social competence was studied taking into account various aspects, the importance of its development for children and adolescents was noted; the influence of the level of social competence development on professional activity and achievements was described; means and methods of its development were studied.

Views on the structure of social competence differ depending on age, level of education, specialization. M. Argyle separated the following components of social competence: social sensitivity; basic interaction skills; reward and approval skills which are important for all social situations; equanimity [1, p. 18]. M. Doktorovych [2] proposed to distinguish in the structure of social competence communicative (communication skills), verbal (ability to express thoughts), socio-psychological (ideas about the diversity of social roles) competences, interpersonal orientation or ego-competence (understanding of gender, national, state, group identity) and the actual social or operational competence (knowledge of social structures). O. Zhukova defined seven elements as components of social competence: knowledge, skills, abilities, understanding, capabilities, experience, values [3, p. 50]. V. Shakhrai described the status-role component (proper social reproduction and functioning), value-dispositional (social values, norms in the internal structure of personality) and communicative, which includes the implementation of social roles and the establishment of social values [4, p. 67-68]. I. Zarubinska emphasized the following components of social competence value-motivational, cognitive, activity, reflexive and personal [5, p. 11].

Thus, scientists estimate social competence in various ways, taking into account the characteristics of the age groups, the level of education and specialization of students. Social competence of foreign students has not been studied in Ukrainian scientific works, its structure has not been determined, scientists have not paid much attention to the formation of social competence of foreign students.

The aim of the work is to determine the structure of social competence of a foreign student, based on methodological approaches and pedagogical principles and to analyse the composition of each component.

The model of formation of social competence of foreign students, based on competence, systemic, culturological, axiological, participatory, environmental approaches, contains the following components: cognitive, value, activity and communicative.

The cognitive component of the social competence of foreign students is characterized by knowledge that allows to socialize effectively in society; self-conception in social relations; perception of social essence; knowledge and understanding of the social roles of a particular society, realization of social reality, social laws of society, where foreign students live. At the core of the cognitive component, in our opinion, is the phenomenon of social intelligence.

Social intelligence is a concept introduced into psychological science by E. Throndike; he described it as a general ability to understand other people and to interact with them [6, p. 231]. According to A. Yuzhaninova [7], social 
intelligence is a system of cognitive qualities of person, it consists of three parts, including socio-perceptual abilities, social imagination and social communication techniques, the level of their formation influences the effectiveness of communication. E. Ivashkevych [8] studied the social intelligence of the teacher, the scientist concluded that it contains three substructural components: cognitive (set of knowledge, rules of understanding human behaviour, relationships based on a system of interpretations), mnemonic (ability to interpret life events, behaviour of other people) and empathic (form of behaviour depending on the environment).

Thus, analysing works about social intelligence in Ukrainian and foreign papers, in particular of G. Allport, J. Guilford, N. Kudryavtseva, S. Weis, Y. Chernozhuk, L. Kabatsyura, we see that all scientists emphasize its importance for building successful interaction in society. Social intelligence is a leading component of human inclusion in the social life, makes a person a participant in modern communication systems and interactions, it allows to understand and predict behaviours of others, gives the ability to adapt to different situations and relationships. Social intelligence unites and regulates cognitive processes associated with the reflection of human social objects. One of the main integral functions of social intelligence is the formation of long-term, stable relationships in society with the prospect of development and positive interaction, which is extremely important for the successful adaptation of a foreign student in a new social environment.

Value component of the social competence of foreign students involves the adoption of standards of social behaviour, the ability to understand and control emotions, understand and anticipate the emotions of others, i.e. the presence of emotional intelligence; tolerance for foreign culture, ethics in relationships, empathy.

The concept of emotional intelligence came from psychological science. G. Gardner, W. Payne, R. Bar-On, L. Wexler studied the importance of emotional intelligence development. In 1990, Peter Salovay and John Mayer in their work defined the concept of emotional intelligence as the ability to control own and others' emotions, ability to distinguish emotions and use this information to control thinking and actions [9, p. 189]. Among the Ukrainian scientists who paid attention to the study of emotional intelligence, we can highlight S. Chelalo, S. Podofiey, S. Ponikarovska, I. Zadorozhna, G. Berezyuk, V. Zarytska, O. Liashch, E. Nosenko, M. Shpak, L. Rakitianska.

Emotional intelligence is the ability to understand own emotional states and the emotions of others, the ability to control them. People with a high level of emotional intelligence are more friendly, smooth-tempered, build understanding with different personalities, they recognize better the emotions of others, have adequate self-esteem, have self-control skills, sense of humour. These qualities are extremely important for international students to adapt successfully to a new environment, they facilitate this process, accelerate it.

Tolerance is respect, perception and understanding of the diversity of cultures of the world, self-expressions of the human personality [10, p. 9]. Tolerance is an integral element of modern social relations, where you can see the problem of interaction of different cultures. This is acute for international students who find themselves in new conditions, in a society with a different culture and a different religion. Tolerance provides the ability to social interaction on the basis of moral and legal norms, established social standards, tolerance for representatives and rules of another culture, readiness to establish partnerships with foreign individuals. Formed tolerance is the main condition for positive and productive communication.

Empathy is the ability of a person to understand the feelings of another person, to respond to experiences. Empathy helps to empathize with all living things; it is the ability to imagine what is happening in the mental sphere of another person, as well as to assess the external world and its internal sensations [11]. Empathy is an important aspect in building relationships, it is able to balance communication, it expands ideas about the lives of others, enriches own emotional experience, develops a system of human values. A person with developed empathy can put himself in the place of another, has the ability to react emotionally to other people's experiences. Empathy promotes the balance of intercultural relations of foreign students, it allows to understand each other, to build relationships on a new level.

Activity component of social competence of foreign students is realized in behaviour that does not contradict the norms of foreign society, in the ability to cooperate in a group, in a team, the ability to perform various social roles inherent in a society, effective social adaptation and psychological flexibility.

The basis of the activity component is social action, a concept from theoretical sociology, which was introduced into science by $\mathrm{M}$. Weber, he considered that the main feature of social action is the focus of one person on another as participants in the interaction. Weber noted that social action involves subjective motivation [12]. Social action is performed according to certain role patterns. The social role of person is given by society and relevant social groups; features of its implementation depend on the internal reserve of the individual, his motivational and semantic sphere, which is revealed in the disposition of the individual needs, interests, values, life goals, social attitudes, strategies [4, p. 50]. To be engaged in social interaction and perform social roles, it is necessary to know what social roles are inherent in a particular social group. Only with this knowledge a foreign student will successfully, quickly and effectively complete the process of adaptation to the new environment.

Adaptation is interaction of the individual and the environment, in the process of which there is a coordination of their structures, functions and behaviour [13, p. 135]. In the process of social adaptation there is an interaction of the individual with the new social environment, so there is a harmonization of requirements and expectations with capabilities and reality. 
In the process of adaptation there is a change in the social qualities of the individual under the influence of the new society. To overcome psycho-physiological, educational and cognitive, socio-cultural difficulties, to integrate into the new society, foreign students need pedagogical support and constant correction of the adaptation process. For a successful process of adaptation, foreign students need a number of skills and abilities, among which psychological flexibility is important.

Communicative component of social competence of foreign students is the ability to verbalize thoughts adequately, mastery of techniques of verbal and nonverbal communication, observation of cultural norms in communication, the ability to prevent conflicts, the ability to resolve conflict situations in case of their occurrence.

The effectiveness of adaptation of foreign students to life in new conditions, the establishment of relationships is determined by the presence of communication skills that allow to adapt quickly to a new society with new rules. Communication skills are an element of communicative activity, it is an activity of establishing connections with another subject of communication, mastering communication skills turns the process of communication into a controlled one; it is the ability to use speech skills for various communication purposes [14]. The basis of the communication process is verbal (language) means, i.e. the process of exchanging information through oral or written language, which is based on a system of established norms. To carry out verbal communication successfully, foreign student must know the language of the country where he is studying, at least at the A2 level.

Nonverbal means of communication are components of the communicative code, they have a symbolic nature and together with the means of speech serve to create, transmit and perceive information [15]. Nonverbal means of communication play an important role in the process of interethnic communication, foreign students sometimes find it difficult to perceive nonverbal elements of communication because in different cultures and societies the same elements carry different semantic load.

The ability to prevent conflicts and successfully resolve them is an integral part of successful communication. Conflict is a clash of opposing goals, interests, opinions, positions or views of the participants in the interaction. $\mathrm{S}$. Freud noted that a person has a conflicting nature, deep layers of his psyche are imprinted in opposition, a person has a tendency to aggression and initial hostility to others [16]. There are many reasons for conflict situations, contradictions can arise at any stage of communication, among motives there is aggression, stress, self-assertion, selfishness, injustice, misunderstanding, errors in the perception of information. Interethnic conflicts can arise on the basis of racial, religious, ideological, national reasons. To prevent escalation of the conflict, it is necessary not to react to conflictogens (actions or words that provoke the conflict), not to succumb to provocations; but the best pattern of behaviour is conflict prevention. It is necessary to learn to understand communication or interaction partners, to be able to identify important situations for the interlocutor, to understand emotions, and to be able to reach a compromise, which is extremely important for creating successful intercultural communication by foreign students.

Conclusions. Thus, studying the social competence of foreign students, the following components of its structure were identified: cognitive (social intelligence), value (emotional intelligence, tolerance, empathy), activity (knowledge of social roles, adaptability) and communicative (verbal and nonverbal communication techniques, the ability to prevent conflicts). This structural model reveals the content of social competence of foreign students. Formed at a high level, all elements of each component indicate a high level of social competence of the foreign student, which allows to speak about a person who has a strong system of knowledge about human interaction in society, developed social intelligence, understands and accepts social values of other cultures, is able to cooperate with different people, perform different social roles, is able to adapt to the requirements of a new society, is able to carry out constructive communication and prevent conflicts.

\section{Bibliography:}

1. Аргайл М. Психология счастья. Санкт-Петербург : Питер, 2004. 272 с.

2. Докторович М. О. Формування соціальної компетентності старшого підлітка з неповної сім'ї : дис. .... канд. пед. наук : 13.00.05 «Соціальна педагогіка». Ін-т проблем виховання АПН України. Київ, 2007. 208 с.

3. Жукова О. А. Дидактична система формування соціальної компетентності студентів гуманітарних спеціальностей класичних університетів засобами ігрових технологій : дис. ... докт. пед. наук : 13.00 .09 «Теорія навчання». Тернопільський національний педагогічний університет імені Володимира Гнатюка, Тернопіль, 2019. 555 с.

4. Шахрай В. М. Теоретико-методичні засади формування соціальної компетентності учнів основної і старшої школи засобами театрального мистецтва : дис. ... докт. пед. наук. Київ. 2016. 534 с.

5. Зарубінська І. Б. Теоретико-методичні основи формування соціальної компетентності студентів вищих навчальних закладів економічного профілю : автореф. дис. ... докт. пед. наук. Інститут вищої освіти НАПН України. Київ, 2011. 39 с.

6. Thorndike E. L. Intelligence and its use. Harper's Magazine. 140. 1920. P. 227-235.

7. Южанинова А. Л. К проблеме диагностики социального интеллекта личности. Проблемы оценивания в психологии. Саратов ун-т, 1984.

8. І Івашкевич Е. 3. Соціальний інтелект як система інтелектуальних здатностей особистості. Проблеми сучасної психології : збірник наукових праць Кам'янець-Подільського національного університету імені Івана Огієнка, Інститут психології імені Г. С. Костюка Національної академії педагогічних наук України. Випуск 32. Кам'янець-Подільський : Аксіома, 2016. C. $153-166$.

9. Salovey P., Mayer J. D. Emotional intelligence. Imagination, Cognition, and Personality. 1990. Vol. 9. P. $185-211$.

10. Декларація принципів толерантності. Схвалена Генеральною конференцією ЮНЕСКО на іiі XXVIII сесії в Парижі 16 листопада 1995 року. Київ, 2000.

11. Креденцер В. В. Емпатія як здатність суб’єкта спілкування. Актуальні проблеми психологї. Том V. Випуск 12. С. $107-144$.

12. Вебер М. Работы Макса Вебера по социологии, религии й культуре. Москва, 1991. 
13. Волков Г. Д., Оконська Н. Б. Адаптація та ï рівні. Харків : НПУ імені Г. С. Сковороди, 2008. 246 с.

14. Соснова К. Розвиток комунікативних здібностей учнів на уроках української мови. Дивослово. 2012. № 7. С. 2-9.

15. Бацевич Ф. С. Основи комунікативної лінгвістики: Підручник. Київ, 2004. 59 с.

16. Freud S. Civilization and its discontents. L. Internationaler Psychoanalytischer Verlag Wien, 1930. 127 p.

\section{References:}

1. Argail, M. (2004). Psykholohiia shchastia [The psychology of happiness]. St. Peterburg: Piter. 272 s. [in Russian]

2. Doktorovych, M. O. (2007). Formuvannia sotsialnoi kompetentnoti starshoho pidlitka z nepovnoi simi. Avtoref. dys. kand. pedahoh. nauk [Formation of social competence of an older teenager from a single-parent family. Abstract of cand. pedag. sci. diss]. Kyiv, 19 s. [In Ukrainian]

3. Zhukova, O. A. (2019). Dydaktychna systema formuvannia sotsialnoi kompetentnosti studentiv humanitarnykh spetsialnostei klasychnykh universytetiv zasobamy ihrovykh tekhnolohii. Dysertatsiia na zdobuttia naukovoho stupenia doktora pedahohichnykh nauk : 13.00.09 "teoriia navchannia" [Didactic system of formation of social competence of students of humanitarian specialties of classical universities by means of game technologies. The dissertation on competition of a scientific degree of the doctor of pedagogical sciences on a specialty 13.00.09 "the theory of training"]. Ternopil, $555 \mathrm{~s}$. [In Ukrainian]

4. Shakhrai, V. M. (2016). Teoretyko-metodychni zasady formuvannia sotsialnoi kompetentnosti uchniv osnovnoi i starshoi shkoly zasobamy teatralnoho mystetstva. Diss. dokt. pedahoh. nauk [Theoretical and methodological principles of formation of social competence of primary and secondary school students by means of theatrical art. Doct. pedag. sci. diss]. Kyiv, $534 \mathrm{~s}$. [In Ukrainian]

5. Zarubinska, I. B. (2011). Teoretyko-metodychni osnovy formuvannia sotsialnoi kompetentnosti studentiv vyshchykh navchalnykh zakladiv ekonomichnoho profiliu. Avtoref. dys. dokt. pedahoh. nauk [Theoretical and methodological bases of formation of social competence of students of higher educational institutions of economic profile. Abstract of doct. pedag. sci. diss]. Kyiv, $39 \mathrm{~s}$. [In Ukrainian]

6. Thorndike, E. L. (1920). Intelligence and its use. Harper's Magazine. 140. p. 227-235.

7. Yuzhaninova, A. L. (1984). K probleme diahnostyki sotsialnoho intellekta lichnosti. Problemy otsenivaniia v psikholohi [On the problem of diagnosing the social intelligence of the individual. Evaluation problems in psychology.]. Saratov. [In Russian]

8. Ivashkevych E. Z. (2016). Sotsialnyi intelekt yak systema intelektualnykh zdatnostei osobystosti [Social intelligence as a system of intellectual abilities of the individual.]. Problemy suchasnoi psykholohii: Zbirnyk naukovykh prats Kamianets-Podilskoho natsionalnoho universytetu imeni Ivana Ohiienka, Instytut psykholohii imeni H. S. Kostiuka Natsionalnoi akademii pedahohichnykh nauk Ukrainy. V 32. Kamianets-Podilskyi, S. 153-166.

9. Salovey, P., Mayer, J. D. (1990). Emotional intelligence. Imagination, Cognition, and Personality. Vol. 9. P. 185-211. [In Ukrainian]

10. Deklaratsiia pryntsypiv tolerantnosti. Skhvalena Heneralnoiu konferentsiieiu YuNESKO na yii XXVIII sesii v Paryzhi 16 lystopada 1995 roku [Declaration of Principles of Tolerance. Approved by the General Conference of UNESCO at its XXVIII session in Paris on November 16, 1995]. (2000). Kyiv. [In Ukrainian]

11. Kredentser, V. V. (2012). Empatiia yak zdatnist subiekta spilkuvannia [Empathy as the ability of the subject to communicate]. Aktualni problemy psykholohii [Current problems of psychology]. Tom V. V. 12. S. 107-144. [In Ukrainian]

12. Veber, M. (1991). Raboty Maksa Vebera po sotsiolohii, relihii i culture [Max Weber's works on sociology, religion and culture]. Moscow. [in Russian]

13. Volkov, H. D., Okonska, N. B. (2008). Adaptatsiia ta yii rivni [Adaptation and its levels.]. Kharkiv, 246 s. [In Ukrainian]

14. Sosnova, K. (2012). Rozvytok komunikatyvnykh zdibnostei uchniv na urokakh ukrainskoi movy [Development of the communal health of scholars at the lessons of the Ukrainian language.] Dyvoslovo [Wonder word], 7. S. 2-9. [In Ukrainian]

15. Batsevyh, F. S. (2004). Osnovy komunikatyvnoi linhvistyky [Basics of communicative linnvistics] Textbook. Kyiv, 59 s. [In Ukrainian]

16. Freud, S. (1930). Civilization and its discontents. L. Internationaler Psychoanalytischer Verlag. Wien, 127 p.

\section{Лукацька Я. С. Структура соціальної компетентності іноземних студентів}

Мета статті - зробити аналіз структури соиіальної компетентності іноземних студентів та виділити компоненти, які б чітко визначали зміст цьього поняття. Соціальна компетентність досліджувалася украйнськими $і$ зарубіжними вченими з урахуванням різних аспектів, зауважувалося значення ї̈ розвитку в різних категорій студентів, але соиіальна компетентність іноземних студентів не вивчалася на належному рівні. Спираючись на методологічні підходи (компетентнісний, системний, культурологічний, аксіологічний, партисипативний, середовищний) та педагогічні принципи, ми визначили модель формування соціальної компетентності іноземних студентів, яка містить такі компоненти: когнітивний, ціннісний, діяльнісний $і$ комунікативний.

Когнітивний компонент характеризується знаннями, щзо дають змогу результативно соиіалізуватися: знання про себе як про суб'єкта соиіальних відносин; знання про свою соиіальну сутність; знання і розуміння соиіальних ролей певного суспільства, усвідомлення соціальної дійсності, суспільних законів соціуму, де знаходяться іноземні студенти. В основі когнітивного компонента, на нашу думку, лежить явище соиіального інтелекту. Ціннісний компонент передбачає прийняття стандартів соціальної поведінки, вміння розуміти і контролювати свої емоції, розуміти $і$ передбачати емоиії оточення, тобто наявність емочійного інтелекту, наявність чітко визначеної власної позиції, толерантність, етичність у взаємовідносинах, емпатія. Діяльнісний компонент втілюється в поведіниі, щзо не суперечить нормам іноземного суспільства, в умінні співпрацювати в групі, умінні виконувати різні соціальні ролі, в результативній соиіальні адаптації та психологічній гнучкості. Комунікативний компонент полягає в умінні адекватної вербалізаичї думок, володіння техніками вербальної і невербальної комунікації, дотриманні культурних норм у спілкуванні, вмінні запобігати конфліктам, здатності вирімувати конфліктні ситуації в разі їх виникнення.

Ця структурна модель розкриває зміст соиіальної компетентності іноземних студентів.

Ключові слова: соціальна компетентність, іноземний студент, когнітивний компонент, ціннісний компонент, діяльнісний компонент, комунікативний компонент, соціальний інтелект, емоційний інтелект, адаптація. 